\title{
Contribution of Integrated Urban Agriculture to Household Income: A Case of
} Kinondoni Municipality, Tanzania

\author{
Kelvin Victor ${ }^{*}$, Fatihiya A. Massawe ${ }^{2}$ and Anna Sikira ${ }^{3}$ \\ Received: $26^{\text {th }}$ January 2017 / Accepted: $1^{\text {st }}$ May 2018
}

\begin{abstract}
Purpose: Urban farmers make efficient utilization of resources by integrating crop-livestockfish subsectors to maximize accrued benefits. However, types of integration practices adopted and associated income outcome are still undocumented. Thus this study specifically assessed the types of integrated urban agriculture (IUA) mostly practiced by farmers, types of livelihood strategies adopted simultaneously with IUA and its contribution to total household income.
\end{abstract}

Research Method: The study adopted cross-sectional research design. Both quantitative and qualitative data were collected from 132 respondents. Descriptive statistics employed to assess livelihood strategies prioritised by integrated urban farmers. Multiple linear regression technique was adopted to model factors influencing IUA annual income.

Findings: The results show that integrated urban agriculture is the most prioritised livelihood strategy to urban farmers. Majority of urban farmers (98.5\%) practising integrated farming concentrated on crop-livestock, while fish-livestock and crop livestock-fish integration adopted only by $0.75 \%$ each. This implies that, majority of urban farmers did not practice fish sub-sector. Integrated urban agriculture gives average annual income of 2295288 TSH (equivalent to 1093\$); which was sufficient for household of six members being above monetary food poverty line per year.

Research Limitation: This study focuses on income livelihood indicator; however, farmers can also, benefit from integrated agriculture through food security, social inclusion and ecology to mention some.

Originality/Value: This study provides an comprehensive layout adopted by integrated urban farmers to benefit from the sub-sectors and what is missing for improvement of the enterprises for improved livelihood outcome in Tanzania

Keywords: Integrated Urban Agriculture, Livelihood Strategy, Income, Household

\section{INTRODUCTION}

Increasingglobalurbanizationandenvironmental threats increase the challenge of ensuring food security for city residents specifically in developing countries (Poulsen, et al 2015). This is attributed to the fact that large share of urban poor income goes to food expenditure. For example, the continuous increases in food prices in Tanzania has a significant effect on Tanzania's growing population of urban poor as their food budget share amounts to 67 per cent (Tasciotti, and Wagner 2015). The efforts to ensure increased productivity to feed the growing population and improving livelihood in general, have been in place. Urban and periurban agriculture (UPA) are increasingly being

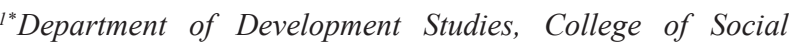
Sciences and Humanities, Sokoine University of Agriculture P.O. Box 3024, Morogoro, Tanzania.victkelvin@gmail.com ORCID http://orcid.org/0000-0002-4588-7210

2 Department of Policy Planning andmanagement, College of Social Sciences and Humanities, Sokoine University of Agriculture, P.O. Box 3035, Morogoro, Tanzania.

${ }^{3}$ Department of Development Studies, College of Social Sciences and Humanities, Sokoine University of Agriculture, P.O. Box 3024, Morogoro, Tanzania.
} 
promoted as a multi-focal strategy for enhancing urban food security and advancing climate change adaptation and mitigation efforts in cities (Padgham et al., 2015).Urban agriculture can have many different expressions, varying from plant/crop production, poultry and livestock to aquaculture farming (De Bon et al., 2010; Drechsel, and Dongus,2010). Urban farming can be practiced through the monoculture system or integrating farming where farmers can involve crop-livestock integration, cropfish integration livestock-fish integration or crop-fish-livestock integration (Ugwumbaet al., 2010). Despite different ways of integration, majority of the urban farmers practice mostly monoculture farming which has been criticised for not being able optimally benefit farmers. Given the limitations of monoculture farming approach, current emphasize is given on practising integrated urban agriculture (Miccoliet al., 2015). It can be argued that, integrated urban agriculture besides increasing productivity many-fold, also removes all the farming constraints (e.g. high cost of inputs and environmental pollution). In addition to that, Integrated urban agriculture (IUA) helps in solving most of the existing economic and ecological problems; it also provides needed means of production such as fuel, fertilizer and feed (Ugwumbaet al., 2010).

A number of studies have been done on urban and peri-urban agriculture among others include integrating land planning in agriculture(Halloran and Magid, 2013), technical efficiency of urban agriculture (Mwajombe and Mlozi, 2015) and governance of urban agriculture (Mkwela, 2014). However, there is dearth of information on contribution of integrated urban farming to households' income. Given the importance of integrated urban agriculture as one way of the enhancing resources used efficiently and existence of a number of farmers in urban areas practicing integrated urban agriculture as their livelihood strategy; thus, it was important to understand the contribution of integrated urban agriculture on household annual income and its influencing factors. Specifically, the paper assessed types of integration adopted by farmers in Dar es Salaam, types of other livelihood strategies adopted by urban farmers simultaneously with integrated urban farming and share of the income from integrated urban agriculture farming income into the total households' income. The information generated from this study enriches the existing body of knowledge on integrated urban farming and inform the policies promoting integrated urban farming on the benefit of the sector in households' income and the ways to improve farmers to engage into full integration.

\section{METHODOLOGY}

The study was conducted in Kinondoni Municipality which is located at $6^{0} 470$, south and $39^{\circ} 160$ East of Dar es Salaam city. Due to close proximity to the equator and the warm Indian Ocean, the city experiences a tropical climatic condition that is favourable for agricultural activities. Kinondoni was chosen to be a study area because it was the leading municipal in pursuing agricultural activities compared to other two municipals within the region (Mlozi et al., 2014).The study adopted a cross-sectional research design.

According to the meeting held between the Centre for Coordination of Agricultural Research and Development for Southern Africa (CCARDESA) project team and Kinondoni Municipal executive office on March 2017, the district has only 205 farmers integrating more than one agricultural subsector; however, the number increased up to 15,000 farmers when considering monoculture (Schmidt, 2012). From the details given by Kinondoni municipal executive office a purposive sampling technique was employed to select six wards. In each ward, a random sampling technique was deployed to get total of 134 integrated urban farmers from a sampling frame that was prepared by listing all integrated urban farmers in each ward. The formula developed by Krejcie and Morgan (1970) was used to get a sample size of 134 respondents; out of which 22.3 (equivalent to 22) respondents 
were interviewed in each ward. The sampling unit was made of households where household's head, or any adult aged above 18 years involved in integrated urban agriculture was interviewed.

The formula states that Samples $\mathrm{n}=\mathrm{N}\left(1+\mathrm{Ne}^{2}\right)^{-}$ ${ }^{1}$ Where: $\mathrm{n}=$ the sample size; $\mathrm{N}=$ the population size; $\mathrm{e}=$ the level of precision; thus $\mathrm{n}=$ $205\left(1+205 \times 0.05^{2}\right)^{-1}=134$

However, due to various field challenges including availability of respondents, 132 households' heads were interviewed.

Focus GroupDiscussions(FGDs)wereorganised in each ward to collected in-depth information to verify the data collected through the survey. Each FGD comprised of 6-8 participants as recommended by Kumar and Kalyani (2011). Further information were collected from key informants who were mostly extension officers from wards (both livestock and crop officers) and one agricultural officer from the district to make a total of 12 key informants.

Qualitative data analysis was done using content analysis while quantitative data were analysed using Statistical Package for Social Sciences (SPSS). Ms excel was used to compute the percentage contribution of IUA to the total household annual income. In relation to this, a multiple linear regression technique was used to evaluate effects of off-farm income, education level, association membership, age of household head and extension visit on total IUA annual income.

The multiple regression model was as follows: $Y=\beta_{0}+\beta_{1} X_{1}+\beta_{2} X_{2} \ldots \ldots+\beta_{5} X_{5}+e$

Where by:

$\mathrm{Y}-$ Integrated Urban Agriculture Income

$\beta_{0}-$ Equation Interception

$\beta_{1-5}-$ Coefficient of regression

$\mathrm{X}_{1}-$ Household off-farm income (Annual income in TSH)

$\mathrm{X}_{2}-$ Farmers' association membership $(0=\mathrm{No}$, $1=$ Yes)
$\mathrm{X}_{3}-$ Extension services (in frequency of extension visit per annum)

$\mathrm{X}_{4}-$ Years of schooling (in number of years)

$\mathrm{X}_{5}-$ Age of household head (in year)

$\varepsilon-\quad$ Error term

In addition, descriptive statistics (frequencies and percentage) were used to assess types of integration adopted by farmers and income share of each livelihood strategy among integrated urban farmers' households income.

\section{RESULTS AND DISCUSSION}

\section{Socio-demographic characteristics}

Majority of integrated urban farmers were aged between 18 to 56 years. This is the active working age; participation by this age group might be influenced by the profit of the subsector or considering the sub sector as an alternate for earning household income. According to Ugwumbaet al., (2010) active participation in any economic activity influenced by others, and age, since majority of participants in integrated urban agriculture are in productive age; hence even performance of the sub sector is likely to be better than their counter parts (aged $\left.60^{+}\right)$. Table 1 also shows that majority of the respondents' household were headed by male. The small number of female headed household in comparison with the number of male headed household might be contributed to the presence of few female headed households; this correlate with Jongwe (2014) findings which hold that; participation on agriculture in urban area was dominated by the household headed by males. Moreover, Majority of the respondents' households had 4-7 members. This might be due to the factor that in Tanzania the average household size is five members per household. Moreover, the household with a higher number of members can have enough labour power for integrated urban agriculture. According to Gallaher et al., (2013) most of the participant in integrated unban agriculture are households with many household members. 
Table 01: $\quad$ Socio-demographic characteristics

\begin{tabular}{lccc}
\hline & & Frequency & Percentage \\
\hline Sex of Household Head & Female & 24 & 18.2 \\
Livestock Keeping & Male & 108 & 81.8 \\
Fish Farming & Men & 53 & 40.2 \\
Horticultural Production & Women & 79 & 59.8 \\
& Men & 2 & 100 \\
Marital Status & Men & 41 & 31.1 \\
& Women & 91 & 68.9 \\
& Single & 7 & 5.3 \\
Education Level & Married & 118 & 89.4 \\
& Divorced & 4 & 3.1 \\
& Widow/Widower & 3 & 2.3 \\
& No Formal Education & 2 & 1.5 \\
Household head Age & Primary & 80 & 60.6 \\
& Secondary & 31 & 23.5 \\
& University/College & 19 & 14.4 \\
& $18-30$ & 18 & 13.6 \\
& $31-43$ & 48 & 36.4 \\
& $44-56$ & 45 & 34.1 \\
& $57-69$ & 17 & 12.9 \\
& 70 and Above & 4 & 3 \\
& $01-3$ & 25 & 18.9 \\
& $04-7$ & 83 & 62.9 \\
& $08-11$ & 14 & 10.6 \\
& $12-15$ & 7 & 5.3 \\
& $16-19$ & 2.3 \\
\hline
\end{tabular}

Source: Field Data May 2017

Type of Integrated Urban Agriculture Practiced by farmers

Findings in Table 2 show that there were three types of integration practiced in the study area; these were crop-livestock integration, livestockfish integration and crop, fish and livestock integration. Majority of farmers (98.5\%) concentrated on crop-livestock integration while only few integrate livestock and fish or crop livestock and fish keeping.

This might be due to the facts that fish sub sector is a new enterprise to majority of developing countries including Tanzania. The study done by Ugwumbaet al., (2010) in Nigeria also concluded that majority of integrated urban farmers in Nigeria focus more on crop livestock integration with minimal number engaging into other types of integration. More emphasis needed to help urban farmers in developing countries not underestimating the potential of integrated urban agriculture, extending their integration to include fish sub-sector, and accruing more benefits. 
Table 02: $\quad$ Types of integration

\begin{tabular}{lcc}
\hline & Frequency & Percentage \\
\hline Crop and Livestock Production & 130 & 98.5 \\
Livestock and Fish Farming & 1 & 0.75 \\
Crop Production, Livestock and Fish Keeping & 1 & 0.75 \\
\hline
\end{tabular}

Source: Field Data May 2017

Findings in Table 3 show that, majority $(87.9 \%)$ processed neither farm produce nor by-product; this is due to lack of enough knowledge of the enterprises and its additional benefits. Even though integrated urban farmers include livestock keepers the use of industrial fertilizer was still pervasive; it was a common trend in integrated urban farmers that they use both organic and inorganic fertilizers in their fields; this is a result of the lack of knowledge and skills about integration. Farmers believed that industrial fertilizer had immediate impact than organic fertilizer. Considering that, important elements of integration are not only limited to use of bio-fertilizer and crop residuals, but it goes further to the bio-gas and farm produce processing (Ugwumbaet al., 2010); thus, partial integration lowers the benefits of integration (Manjunatha et al., 2014). This imply that, farmers are not benefiting much from integration.

\section{Livelihood Strategies of Integrated Urban Farmers}

Farmers do not only depends on IUA as their livelihood strategy in urban areas, rather IUA goes along with other livelihood strategies. The paper shows that, integrated urban agriculture is the highly prioritised livelihood strategy among integrated urban farmers $(87.9 \%)$ followed by business activities (9.8\%) and salaried job (5.3\%) (See Table 4). The study findings show that, a total of five livelihood strategies including integrated urban agriculture, business, technician/formal employment, and artisan/ handcraft are livelihood strategies carried out by integrated urban farmers. However, regardless of multiple livelihood strategies, $87.9 \%$ of all selected farmers ranked integrated urban agriculture to be the top livelihood strategy than other livelihood strategies; the rest are salaried employment, business and technicians based on their level of priorities (Table 4). Generally, literatures on agriculture show that, majority of farmers engages in off-farm activities to diversify their livelihood and accommodate fluctuation in agricultural production (Smaleet al., 2016; Kassaet al., 2017; Su et al., 2015). However, in urban setting, the scenario is vice versa, people engage in agricultural activities for the purpose of diversifying their livelihood due to vulnerabilities/insecurity and insufficient income obtained from the formal employment. However, off-farm livelihood strategy remains crucial for farmers' households as it can contribute to higher farm production and larger expenses on purchased inputs, while it decreases the use of family labour (Babatunde, 2015).

\section{Table 03: $\quad$ Elements of integration}

\begin{tabular}{lcc}
\hline & Practising & Not Practising \\
\hline Farm Produce processing & $16(12.1)$ & $116(87.9)$ \\
By-Product Processing & $29(22)$ & $103(78)$ \\
Fertilizer Inorganic Uses & $78(59.1)$ & $54(40.9)$ \\
Organic Fertilizer Uses & $96(72.7)$ & $36(27.3)$ \\
\hline
\end{tabular}


Table 04: Livelihood strategies prioritization and ranking by farmers

\begin{tabular}{lcccc}
\hline Livelihood Strategies & First & Second & Third & Fourth \\
\hline Integrated Urban Agriculture & $116(87.9)$ & $12(9.1)$ & $2(1.5)$ & $2(1.5)$ \\
Business & $6(3.8)$ & $13(9.8)$ & $0(0.0)$ & $0(0.0)$ \\
Technical activities/jobs & $7(5.3)$ & $3(2.3)$ & $5(4.8)$ & $0(0.0)$ \\
Natural Resources & $0(0.0)$ & $0(0.0)$ & $1(0.8)$ & $0(0.0)$ \\
\hline
\end{tabular}

Source: Field Data May 2017

Contribution of Integrated Urban Agriculture to income of respondents

Integrated urban farmers have various livelihood strategies to contribute to their household income. This makes the contribution of IUA to the total households' income to diverge. The study findings (Table.5) show that majority $(81 \%)$ of respondents reported that integrated urban agriculture contributes around 81-100 percent to its total household income; they are the people whose primary livelihood strategy is agriculture; thus, they dedicate their capital onto it (Cabannes, 2012).

Despite the high level of contribution of IUA into total household income, the study finds the contribution from other livelihood strategies run simultaneous with IUA by farmers. Each livelihood strategy has its unique contribution to the household income; the income generated through those livelihood strategies are the one that determines total annual household income. Integrated urban agriculture also recorded higher income to the overall household income in comparison to other household incomes; however, it was also among household strategies with least income contribution to some households. The reason for IUA to depict least annual income might be due to the fact that, there are some farmers who keep livestock and grow crops for domestic uses only (Maitra et al., 2015), thus selling of produce is only optional. The standard deviation of the income generated through integrated urban agriculture was the highest when compared to others; reflect high income deviation among integrated urban farmers due to various factors such as farming size (number of livestock/fish and land size), technology employed (improved/ high breeds, irrigation, greenhouse and animal feeds) and farm management (Bowman and Zilberman, 2013). Although the mean annual income accrued through was in third position after salary income and technical activity (2 295 288 TSH equivalent to $1093 \$$ ), it was sufficient for a family to be above monetary food poverty line in Tanzania based on monthly monetary value of $31,879 \mathrm{TSH}$ (equivalent to $15.2 \$$ ) per adult equivalent. This signifies the importance of IUA income to the total household income.

Table 05: Contribution of integrated urban agriculture to household income

\begin{tabular}{lcc}
\hline IUA Contribution to Household income (\%) & Frequency & Percent \\
\hline $1-20$. & 3 & 2.3 \\
$21-40$ & 5 & 3.8 \\
$41-60$ & 8 & 6.0 \\
$61-80$ & 9 & 6.8 \\
$81-100$ & 107 & 81.1 \\
Total & 132 & 100.0 \\
\hline
\end{tabular}


Table 06: Income contributed by each livelihood strategy

\begin{tabular}{lccccc}
\hline Livelihood Strategy & Mean & Count & Std. Deviation & Minimum & Maximum \\
\hline IUA & 3579624 & 132 & 4734812 & 200000 & 27995000 \\
Business Activities & 1729375 & 16 & 3636573 & 200000 & 15000000 \\
Salaried Employment & 4633333 & 6 & 4262237 & 1000000 & 10800000 \\
Technical Activities & 3671429 & 7 & 3293283 & 900000 & 9000000 \\
\hline
\end{tabular}

Source: Field Data May 2017

Factors affecting integrated urban farmers annual household income

Findings in Table 7 present determinants of annual income of integrated urban agriculture annual income. Multiple regression models are used to assess factors influencing their annual income generated from integrated urban agriculture. The significant level is measured at $5 \%$. The regressed variables $\mathrm{R}$ square were 0.459 . This means that, the independent variables explained variation of dependent variables by $45.9 \%$. The remaining $54.1 \%$ undoubtedly was due to other factors that are not included in the model and/or research errors (Ibitoye et al., 2016; Mendenhall and Beaver, 1991). From five explanatory variables entered in a model, (Household off-farm Income, farmers' association membership, extension worker visits, year of schooling, and age of household head) frequency of extension visit two variables (year of schooling and association membership) were significant $(p<0.05)$ to household's income. Year of schooling was statistically significant with a negative influence to household income ( $p=0.012$ ).
This implies that as household education increases the income accrued from integrated urban agriculture decreases since most of household members are engaged in professional employment based on their education level. This suggests that, as the people are educated the less income would be generated through agriculture because they generate more income from off-farm activities including formal employment (Smale et al., 2016; Kassa et al., 2017; Su et al., 2015).

Participation in association was statistically significant with positive influence to household's income $(\mathrm{P}=0.047)$. This implies that as household member participates in association they are likely to benefit through trainings, credits and sharing of experience with their fellow farmers. The trainings, credits and knowledge obtained through participation in association increase farmers' abilities on efficient management of their farming activities thus increased increasing productivity as well as income.

Table 07: $\quad$ Factors affecting integrated urban agriculture income

\begin{tabular}{|c|c|c|c|c|c|c|c|}
\hline & \multicolumn{2}{|c|}{$\begin{array}{l}\text { Unstandardized } \\
\text { Coefficients }\end{array}$} & \multirow{2}{*}{$\begin{array}{c}\text { Standardized } \\
\text { Coefficients } \\
\text { Beta }\end{array}$} & \multirow[b]{2}{*}{$\mathrm{t}$} & \multirow[b]{2}{*}{ Sig. } & \multicolumn{2}{|c|}{$\begin{array}{l}95.0 \% \text { Confidence } \\
\text { Interval for B }\end{array}$} \\
\hline & B & Std. Error & & & & $\begin{array}{l}\text { Lower } \\
\text { Bound }\end{array}$ & $\begin{array}{l}\text { Upper } \\
\text { Bound }\end{array}$ \\
\hline (Constant) & 6.62 & 1.036 & & 6.39 & 0 & 4.471 & 8.768 \\
\hline Year of Schooling & -0.059 & 0.022 & -0.489 & -2.728 & 0.012 & -0.105 & -0.014 \\
\hline Association Membership & 0.481 & 0.229 & 0.351 & 2.101 & 0.047 & 0.955 & 0.006 \\
\hline Extension Workers Visits & 0.312 & 0.209 & 0.333 & 1.489 & 0.151 & -0.122 & 0.746 \\
\hline Off Farm Income & 0.125 & 0.133 & 0.173 & 0.945 & 0.355 & -0.15 & 0.4 \\
\hline HH Head Age & -0.008 & 0.01 & -0.188 & -0.869 & 0.394 & -0.028 & 0.011 \\
\hline
\end{tabular}

Source: Field Data May 2017 


\section{CONCLUSIONS AND} RECOMMENDATION

The findings show that there is very limited livestock-fish integration, crop-livestock-fish integration; majority of farmer concentrated on crop-livestock integration. Thus, there is a need for government and development agents to strengthen farmers' ability on fish subsector. The paper concludes that integrated urban agriculture has significant contribution to household income; it contributes around 81100 percent to total annual income for majority of households in the study area. Farmers in urban areas normally practice IUA along with other livelihood strategies such as professional employment, business and technical activities. However, the multiple linear regression showed that these off-farm livelihood strategies have a positive contribution to IUA income but not significant.

Thus, considering the important contribution of IUA to household income and environment, urban farmers should be encouraged to practice integration rather than monoculture.Since majority of farmers were practising partial integration with major focus on crop-livestock integration, sensitization is needed to help farmers practice full integration that involves processing of farm produce and farm byproduct.

In addition, farmers should be encouraged to integrate fish subsector with other sub-sectors such as crop and livestock since fish keeping is a newly growing enterprise.

\section{Data availability statement}

The data that support the findings of this study are available with Augustine Mwandya (PhD) (Email: - mwandya@sua.ac.tz or mwandya@ yahoo.co.uk) however, restrictions apply to the availability of these data, which were used under license for the current study, and so are not publicly available. Data are however available from the authors upon reasonable request and with permission of with Augustine Mwandya $(\mathrm{PhD})$.

\section{ACKNOWLEDGEMENT}

The authors wish to thank the Centre for Coordination of Agricultural Research and Development for SouthernAfrica(CCARDESA) for financial support during data collection through its project at Sokoine University of Agriculture in Morogoro, Tanzania.

\section{REFERENCE}

Babatunde R.O (2015). On-farm and Off-farm works: Complement or substitute? Evidence from Nigeria. Working Paper No.2015/02. DOI: http://dx.doi.org/10.1596/1813-9450-7213

Bowman, M, S and Zilberman, D. (2013). Ecpnomic Factors Affecting Diversified Farming System. Ecology and Society 18(1):33-47. DOI: http://dx.doi.org/10.5751/es-05574-180133

Cabannes, Y. (2012). Financing Urban Agriculture, nternational Institute for Environment and Development (IIED).24(2): 665-683. DOI: http://dx.doi.org/10.1177/0956247812456126

De Bon, H., Parrot, L., \& Moustier, P. (2010). Sustainable urban agriculture in developing countries. A review. Agronomy for sustainable development, 30(1), 21-32. DOI: http:// dx.doi.org/10.1051/agro:2008062

Drechsel, P., \& Dongus, S. (2010). Dynamics and sustainability of urban agriculture: examples from sub-Saharan Africa. Sustainability Science, 5(1), 69. DOI: http://dx.doi.org/10.1007/ s11625-009-0097-x 
Gallaher, C.M., Kerr, J.M., Njenga, M., Karanja, N.K. and WinklerPrins, A.M., (2013). Urban agriculture, social capital, and food security in the Kibera slums of Nairobi, Kenya. Agriculture and human values, 30(3):389-404. DOI: http://dx.doi.org/10.1007/s10460-013-9425-y

Halloran, A. and Magid, J., (2013). Planning the unplanned: incorporating agriculture as an urban land use into the Dar es Salaam master plan and beyond. Environment and Urbanization, 25(2):541-558. DOI: http://dx.doi.org/10.1177/0956247813500903

Ibitoye, S.J., Shaibu, U.M., Sale, F.A., and Frank, O.E. (2016). Assessment of the Influence of Urban Agriculture on Household Income: Evidence from Kogi State, Nigeria. International Journal of Agricultural and Veterinary Sciences 2 (3): 107 -115. DOI: http://dx.doi. org/10.18819/ijavs.2016.1558

Jongwe A. (2014) Synergies Between urban agriculture and urban household food security in Gweru City, Zimbabwe. Journal of Development and Agricultural Economics 6(2):59-66. DOI: http://dx.doi.org/10.5897/jdae2013.0506

Kassa, B., Kassa, B., \& Aregawi, K. (2017). Off-farm participation decision and its impact on crop yield in Northern Ethiopia. Journal of Development and Agricultural Economics, 9(2), 1625. DOI: http://dx.doi.org/10.5897/jdae2016.0757

Krejcie, R.V., \& Morgan, D.W., (1970). Determining Sample Size for Research Activities. Educational and Psychological Measurement 30: 607-610. DOI: http://dx.doi. org/10.1177/001316447003000308

Kumar, D. and Kalyani, B. (2011). Motivational factors, entrepreneurship and education: Study with reference to women in SMEs. Journal of Psychology and Business, 3 (3):14-35. DOI: http://dx.doi.org/10.5296/ber.v2i1.1434

Maitra, C. and Rao, D.P., 2015. Poverty-Food Security Nexus: Evidence from a Survey of Urban Slum Dwellers in Kolkata. World Development, 72 (2015):308-325. DOI: http://dx.doi. org/10.1016/j.worlddev.2015.03.006

Manjunatha. S.B., Shivmurthy, D. Sunil, A. S., Nagaraj, M.V., and Basavesha, K.N. (2014). Integrated Farming System - An Holistic Approach: A Review. Journal of Agriculture and Allied Sciences 3(4):30-38. DOI: http://dx.doi.org/10.1016/0167-8809(89)90036-4

Mendenhall, W. W., and Beaver, R.J. (1991). Introduction to Probability and Statistics. WPS-Kent Publication Co. Boston. DOI: http://dx.doi.org/10.2307/2684586

Miccoli, S., Finucci, F. and Murro, R., (2015). Towards integrated urban agriculture systems: economic and valuation aspects. Aestimum, 51-64. pp. DOI: http://dx.doi.org/10.1016/j. aaspro.2016.02.017

Mkwela H. S. (2014), Governance of agriculture in the cities of developing countries; Local leaders' perspective. Journal of Geography and regional planning Vol 7(3) 36-46. DOI: http://dx.doi.org/10.5897/jgrp2013.0391

Mlozi, M.R.S., Lupala, A., Chenyambuga, S.W., Liwenga. E. and Msogoya, T. (2014). Building Urban Resilience: Assessing Urban and Peri-urban Agriculture in Dar es Salaam, Tanzania. (Edited by Padgham, J. and Jabbour, J.) United Nations Environment Programme (UNEP). Nairobi, 18-19 pp. DOI: http://dx.doi.org/10.5897/ingoj12.021 
Mwajombe, K, K, and Mlozi, M, R, S, (2015). Measuring Farm-level Technical Efficiency of Urban Agriculture in Tanzanian Towns: The Policy Implications. World Journal of Social Science 2, (1): 62-72. DOI: http://dx.doi.org/10.5430/wjss.v2n1p62

Padgham, J., Jabbour, J., \& Dietrich, K. (2015). Managing change and building resilience: A multistressor analysis of urban and peri-urban agriculture in Africa and Asia. Urban Climate, 12, 183-204. DOI: http://dx.doi.org/10.1016/j.uclim.2015.04.003

Poulsen, M. N., McNab, P. R., Clayton, M. L., \& Neff, R. A. (2015). A systematic review of urban agriculture and food security impacts in low-income countries. Food Policy, 55, 131-146. DOI: http://dx.doi.org/10.1016/j.foodpol.2015.07.002

Schmidt, S. (2012). Getting the policy right: urban agriculture in Dar es Salaam, Tanzania. International Development Planning Review, 34(2), 129-145. DOI: http://dx.doi. org/10.3828/idpr.2012.9

Smale, M., Kusunose, Y., Mathenge, M.K. and Alia, D., (2016). Destination or distraction? Querying the linkage between off-farm work and food crop investments in Kenya. Journal of African Economies, 25(3):388-417. DOI: http://dx.doi.org/10.1093/jae/ejv032

Su W., Liu C, Zhang L., Luo. R., and YI H, (2015) Household-level linkages between off-farm employment and agricultural fixed assets in rural China, China Agricultural Economic Review, 7 (2):185-196. DOI: http://dx.doi.org/10.1108/caer-07-2014-0075

Tasciotti L. and Wagner (2015). Urban Agriculture and dietary diversity: Empirical evidence from Tanzania. The European Journal of Development Research 27 (5): 631-649. DOI: http:// dx.doi.org/10.1057/ejdr.2014.38

Ugwumba, C.O.A., Okoh, R.N., Ike, P.C., Nnabuife, E.L.C., and Orji, E.C. (2010). Integrated Farming System and its Effect on Farm Cash Income in Awka South Agricultural Zone of Anambra State, Nigeria American-Eurasian J. Agric. \& Environ. Sci., 8 (1): 01-06, 2010. DOI: http://dx.doi.org/10.3923/aj.2010.229.233 